Iranian Journal of Breast Diseases. 2021;14(3):46-56.
Original Article

\section{Interactive Effect of 6 Weeks of Aerobic Exercise and Quercetin Supplementation on TIE-2 and VEGF-A Expression in Tumor Tissue of Female Mice with Breast Cancer}

\author{
Jalali $\mathbf{Z}^{1}$, Shahidi $\mathbf{F}^{2 *}$ \\ ${ }^{1} \mathrm{Ph} . \mathrm{D}$. Student in Exercise Physiology, Faculty of Physical Education and \\ Exercise Sciences, Shahid Rajaee Teacher Training University, Tehran, Iran \\ ${ }^{2}$ Department of Exercise Physiology, Faculty of Physical Education and \\ Exercise Sciences, Shahid Rajaee Teacher Training University, Tehran, Iran
}

Receive: 29/5/2021

Accepted: 18/7/2021

"Corresponding Author: fereshteh_shahidi98@yahoo.com

Ethics Approval: IR.SSRI.REC.1398.595

\begin{abstract}
Introduction: In recent decades, the significant role of angiogenesis in the growth and metastasis of cancer has led to much research in this field. The aim of this study was to investigate the interaction effect of 6 weeks of continuous aerobic training and quercetin on TIE-2 and VEGF-A expression in female mice with breast cancer.
\end{abstract}

Methods: Twenty-four female BALB/c mice with breast cancer were randomly divided into 3 groups: tumor $(\mathrm{T})$, tumor+aerobic exercise $(\mathrm{T}+\mathrm{AE})$, and tumor+aerobic exercise+quercetin $(\mathrm{T}+\mathrm{AE}+\mathrm{Q})$. The $\mathrm{T}+\mathrm{AE}$ group and the $\mathrm{T}+\mathrm{AE}+\mathrm{Q}$ group performed endurance running exercise on a treadmill for 6 weeks, 5 days per week, 60 minutes per session, with a gradual increase in intensity over the training period. The $T+A E+Q$ group was injected with $110 \mathrm{mg} \cdot \mathrm{kg}^{-1}$ of quercetin solution for 6 weeks, $/ 3$ days per week/ in addition to exercise. Eventually, the mice were killed, and the tumor tissues were removed and frozen in liquid nitrogen. The expression of TIE-2 and VEGF-A genes was measured using real-time PCR. $\triangle \mathrm{Ct}$, $\Delta \Delta \mathrm{Ct}$, and the fold change were calculated, and one-way analyses of variance with Tukey post hoc tests were used to analyze the data at a significance level of 0.05. Data analysis was conducted using the GenEx software.

Results: The results showed that $\mathrm{T}+\mathrm{AE}+\mathrm{Q}$ interaction significantly reduced VEGF-A expression (4.09 times decrease) compared with the $\mathrm{T}$ group $(\mathrm{P}<0.05)$. Quercetin consumption in the $\mathrm{T}+\mathrm{AE}+\mathrm{Q}$ group significantly reduced VEGF-A expression (2.72 times) compared with the $\mathrm{T}+\mathrm{AE}$ group $(\mathrm{P}<0.05)$., However, aerobic exercise alone had no effect on VEGF-A expression. Also, aerobic exercise alone or in combination with quercetin had no effect on TIE-2 expression.

Conclusion: The interaction of aerobic exercise and quercetin supplementation may be effective in inhibiting tumor angiogenesis.

Keywords: Breast Cancer, Aerobic Exercise, Quercetin, TIE-2 Receptor, Vascular Endothelial Growth Factor 


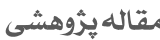

تاثير تعاملى \& هفته تمرين هوازى و مصرف مكمل كوئرستين بر بيان TIE-2

\section{لوستان}

زهره جلالى'، فرشته شهيدى " م"

'دانشجوى دكترى فيزيولوزى ورزشى، دانشكده تربيت بدنى و علوم ورزشى، دانشكاه تربيت دبير شهيد

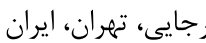
rكروه فيزيولوزى ورزش، دانشكده تربيت بدنى و علوم ورزشى، دانشكاه تربيت دبير شهيد رجايى، تهران، ايران
جكيده

مقدمه: در جند دهه اخير، نقش هشمگير آنزيوزنز در رشد و متاستاز سرطان باعث تحقيقات

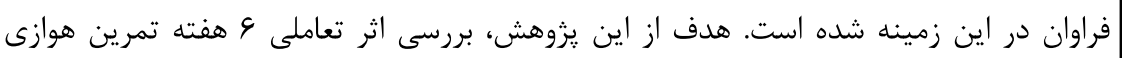

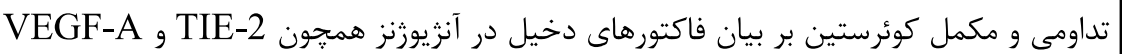

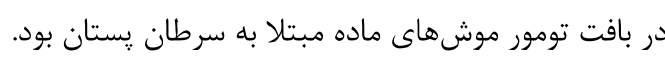

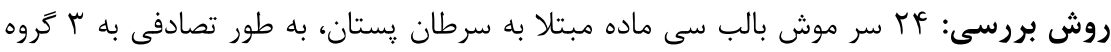

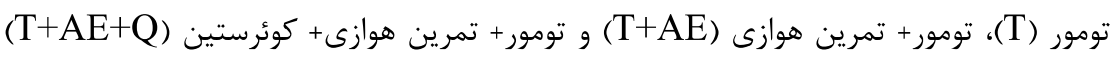

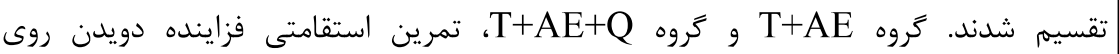

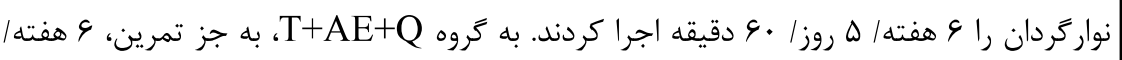

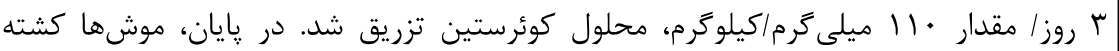

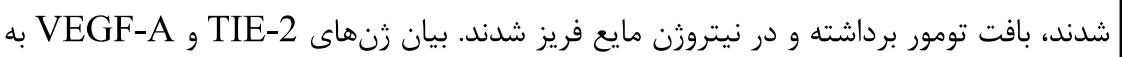

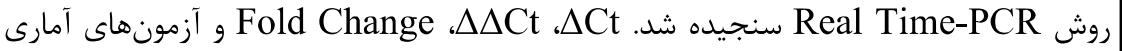

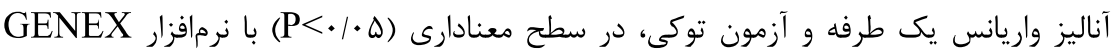
محاسبه شد. يافته ها: نتايج نشان داد تعامل T+AE+Q باعث كاهش معنادار بيان زن VEGF-A لشن

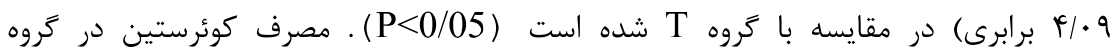

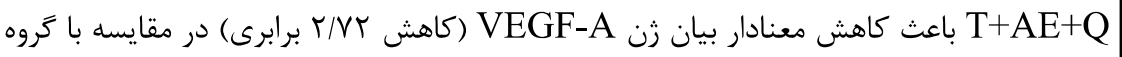
(P+AE

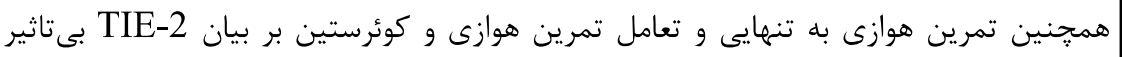
نتيجهَيرى: تعامل تمرين هوازى و مصرف مكمل كوئرستين احتمالا در مهار آنزيوزنز تومور موثر است.

وازههاى كليدى: سرطان هُتان، تمرين هوازى، كوئرستين، گيرنده TIE-2، فاكتور رشد

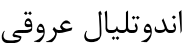

فصلنامه بيمارى هاى يستان ايران

$1 \varepsilon \cdots ! 1 \varepsilon(r): \varepsilon 7-07$

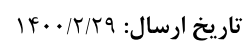

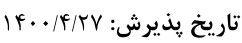

"نويسنده مسئول:

fereshteh_shahidi98@yahoo.com 
آنزيوزنز، باعث افزايش نفوذيذيرى عروق مىشود. افزايش

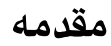
نفوذيذيرى، منجر به خروج يروتئينهاى يلاسمايى و ورود آنها به فضاى ميانبافتى و مهاجرت و تكثير سلولهاي

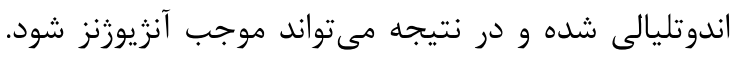

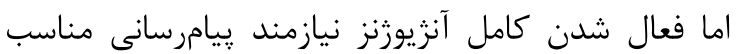

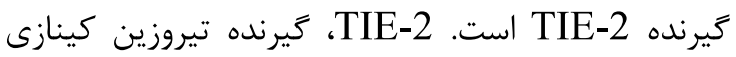
مخصوص سلولهاى اندوتليال است كه توسط دو ليخاند

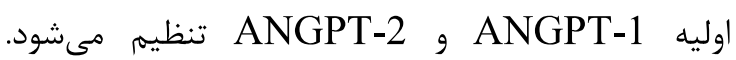
ANGPT-1 پايدارى و استحكام اتصالات بين سلولى و اتصالات ميان

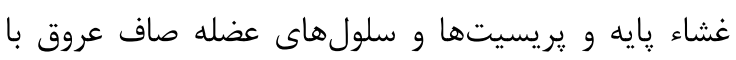
سلول هاى اندوتليال مىشود. ANGPT-2 با - ANGPT

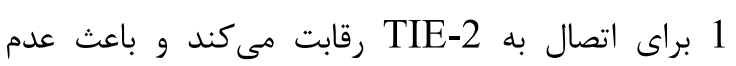

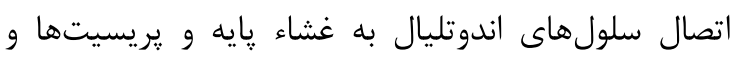

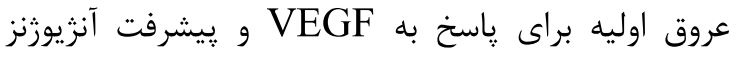

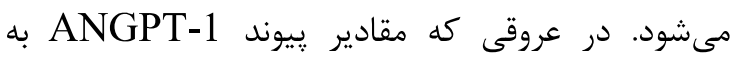

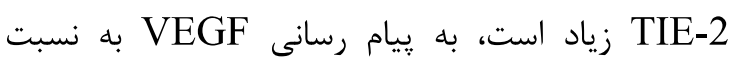

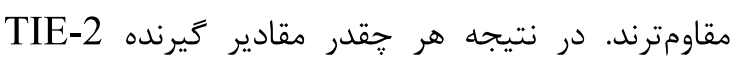

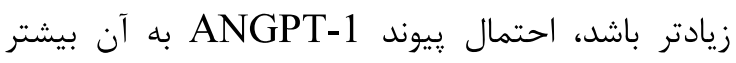

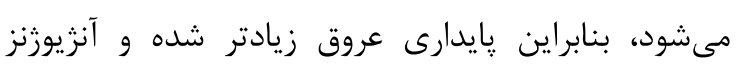

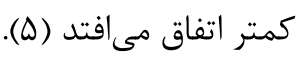

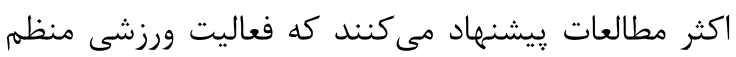
بلهور كلى خطر ابتلا به سرطان را كاهش مىدهد و والن

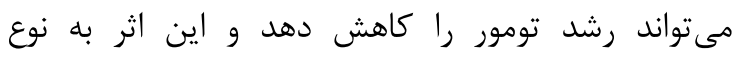

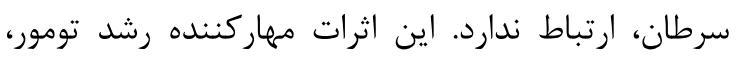

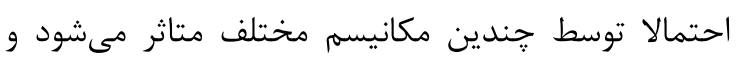

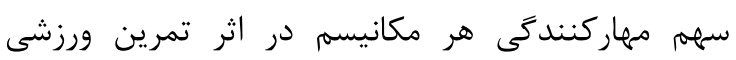

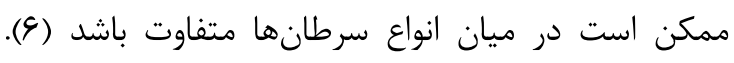
همجنين مشخص شده است كه فعاليت ورزشى با تغيير مسير VEGF-A و TIE-2، منجر به كاهش آنزيوزنز عروق تومور، بازسازى عروق تومور و در نتيجه كاهش رشد

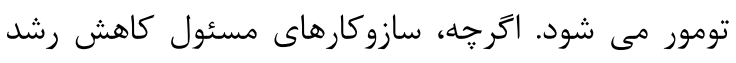
تومور در اين مسيرها، بهطور كامل شناخته نشده است. در در

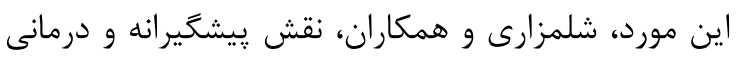

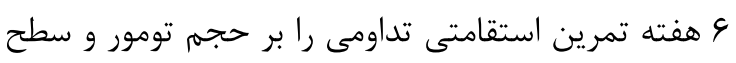

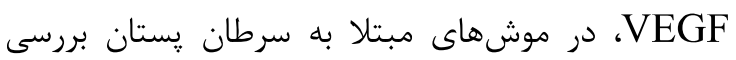

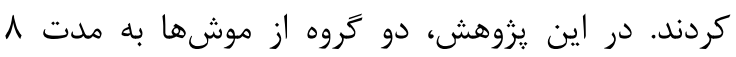

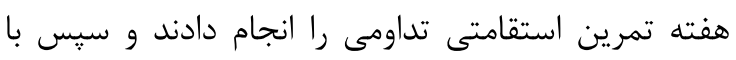

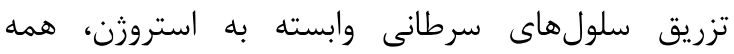

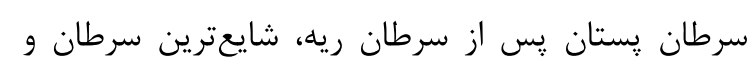

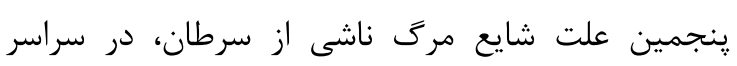

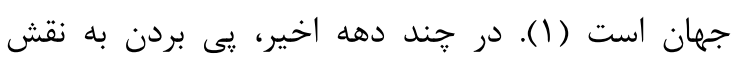

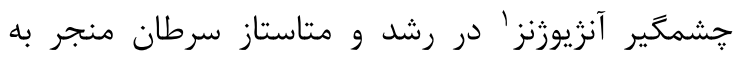
معطوف شدن تحقيقات فراوان به سوى مفاهيه بالينى و

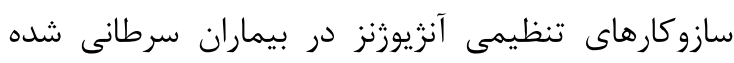

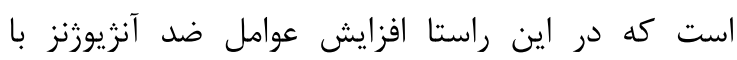

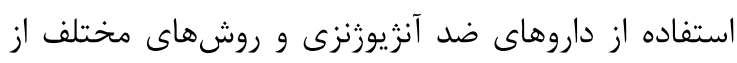

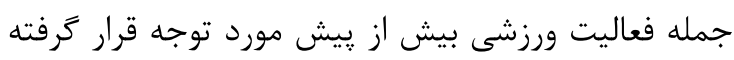

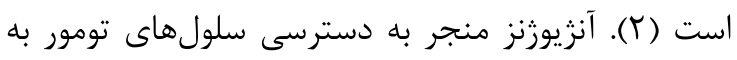

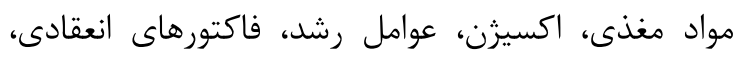
آنزيمهاى يروتئوليتيك و عوامل فيبرينوليتيك مى شى شود و در نتيجه نقش حياتى در رشد و متاستاز تومور دارد (بان).

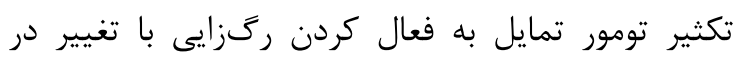

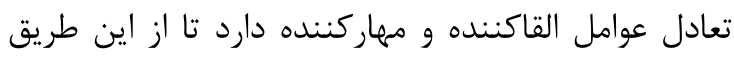

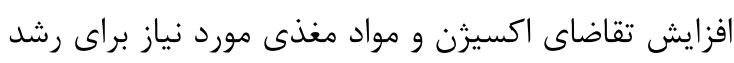

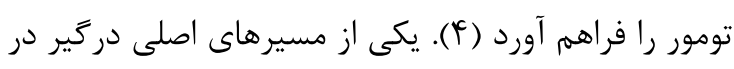

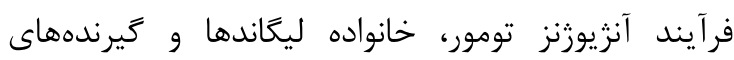
فاكتور رشد اندوتليال عروقى (VEGF) است. بيان بيش نورن

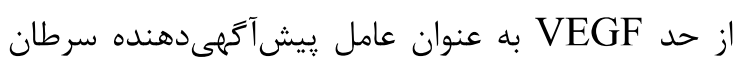

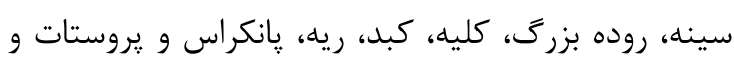

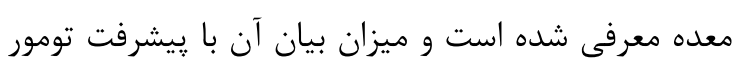

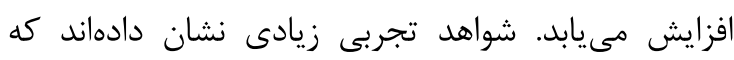

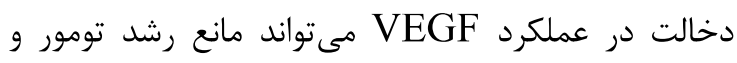

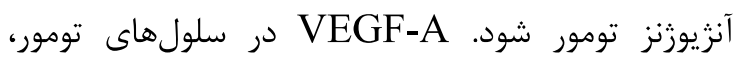

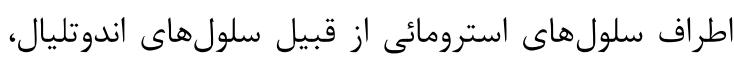

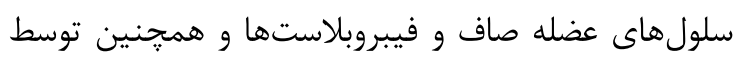

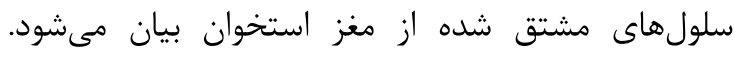

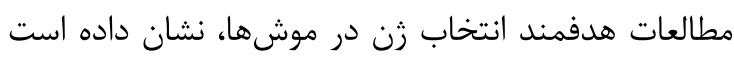

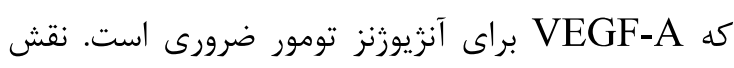

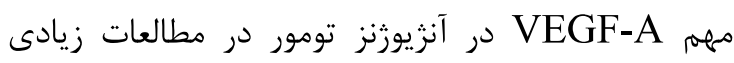

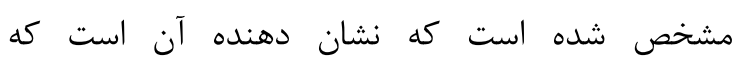

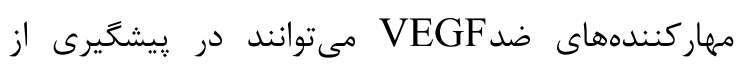

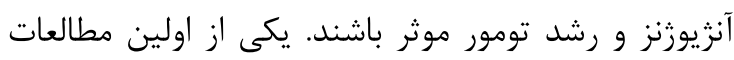

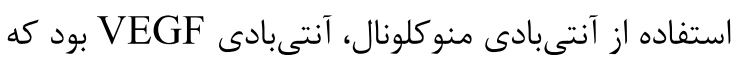

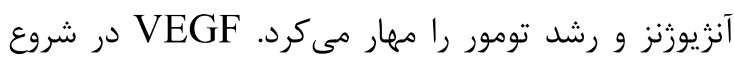

\footnotetext{
${ }^{1}$ Angiogenesis
} 
تداومى باعث كاهش معنادار بيان TIE-2 و كاهش حجم تومور مى شود (1). از سويى ديكر، مكمل يلىفنولى كوئرستين (Quercetin)

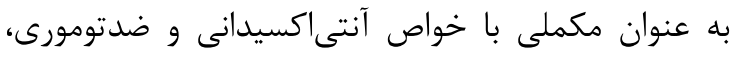
مورد توجه يزوهشكران قرار كرفته است. كوئرستين يكى از از

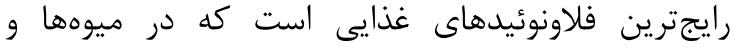

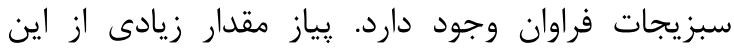

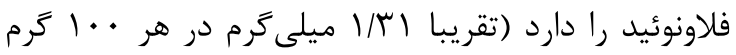

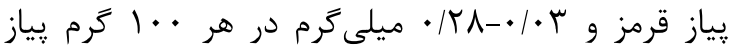
سفيد و زرد). يزوهشها نشان دادهاند كوئرستين علاوه بر بران

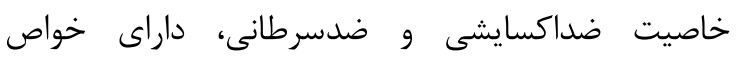
ضدالتهابى، ضدديابتى و ضدميكروبى نيز مىباشد. خواص

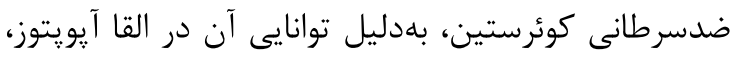

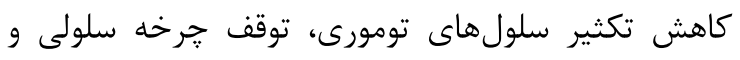

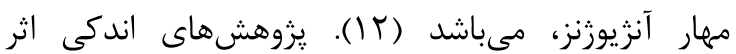
كوئرستين بر بيان VEGF-A ران بررسى كردهاند و يزوهشى كه تاثير تعاملى مصرف كوئرستين و فعاليت

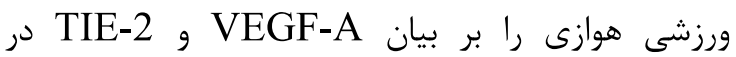
سرطان يستان بررسى كرده باشد، يافت نشد.

\section{مواد و روشها}

نوع يزوهش حاضر و روش آن تجربى و توسعهاى است و در آن همه اصول اخلاقى كار با حيوانات آزمايشخاهى مورد تاييد كميته اخلاق يزوهشكاه علوم ورزشى به شماره آناره

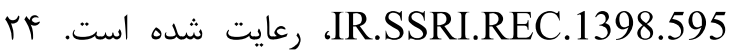

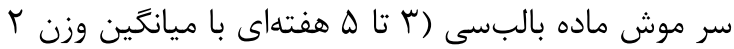

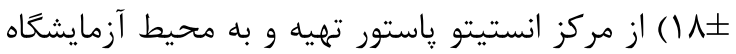

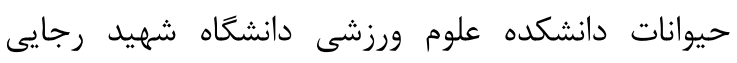
منتقل كرديد. پس از آشنايى با محيط جديد، موشها بلهور تصادفى به ب كروه ^ تايى تومور (T) (ايجاد تومور

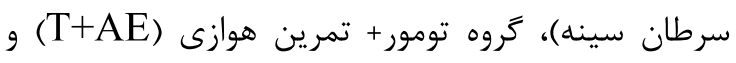

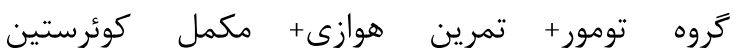
تقسيم شدند. موشها، براى ساز كار شدن با محيط جديد در قفسههاى يلكسى كلاس با درب تورى با بال

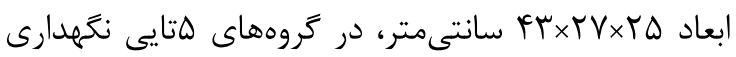

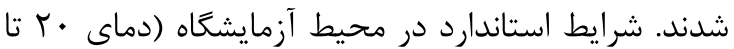
F

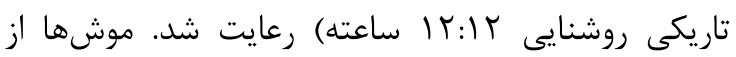

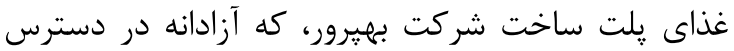

موشها به سرطان يستان مبتلا شدند. گَروه اول شامل موشهايى بود كه قبل از ابتلا به سرطان تمرين نكرده بودند و كروه دوم، شامل موشهايى بود كه قبل از ابتلا به سرطان، تمرين كرده بودند. گروه سوم، موشهايى بود بودند كه قبل از ابتلا به سرطان، تمرين كرده بودند، اما بعد از بردئ تزريق سلولهاى سرطانى، تمرين نكردند. گروه اول و دوم،

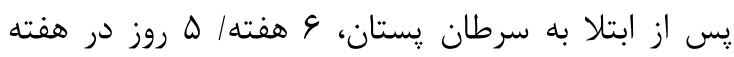

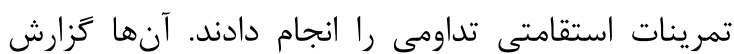
كردند ميزان رشد تومور و مقدار VEGF در كروهدوم كه يس از سرطانى شدن تمرين استقامتى انجام دادند نسبت

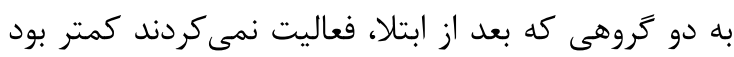

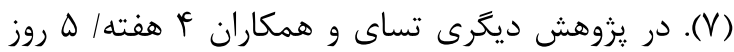

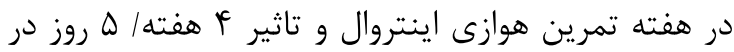
هفته تمرين هوازى تداومى و را بر حجم تومور و سطوح

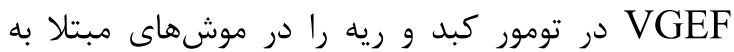

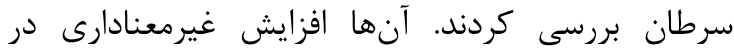

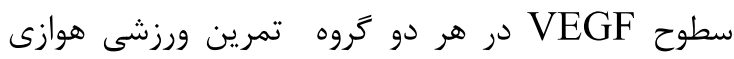

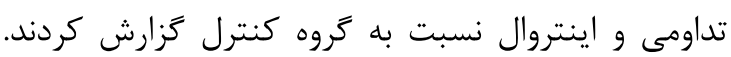
همجنين بيان كردند كه تمرين ورزشى تغييرى در حجم تومور موشهاى مبتلا به سرطان ايجاد نكرده است (^).

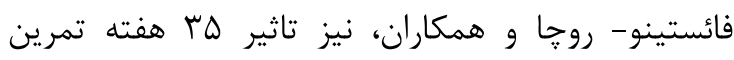
استقامتى دويدن روى تردميل را بر سطح

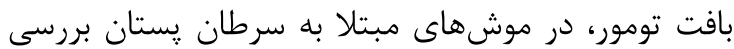

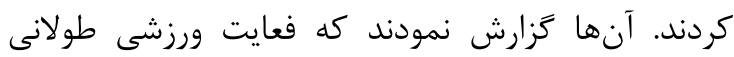

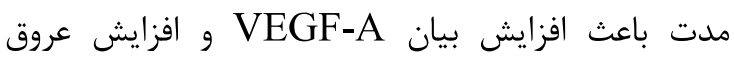
تومور مى مردد (9). در مطالعه ديخرى، خليقفرد و همكاران، تاثير 1 هفته تمرين هوازى تناوبى را بر بيان

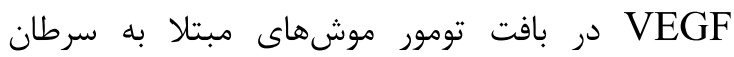
يستان، بررسى كردند و كاهش معنادار بيان VEGF

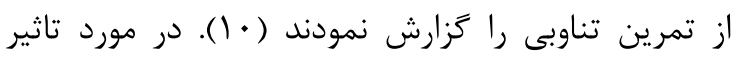

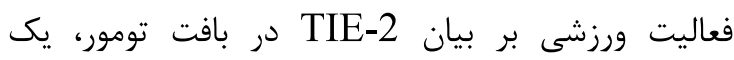

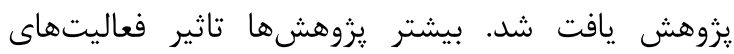

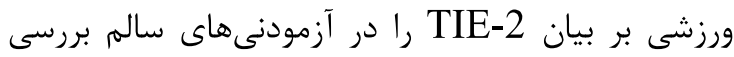

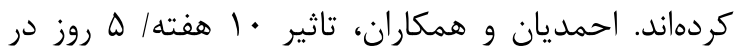

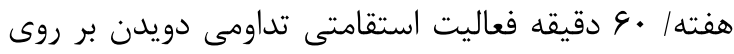

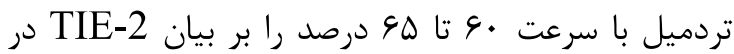

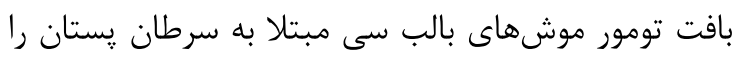

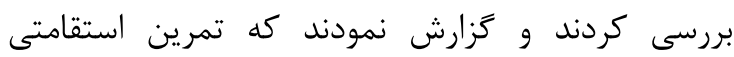


يروتكل تزريق زير صفاقى كوئرستين

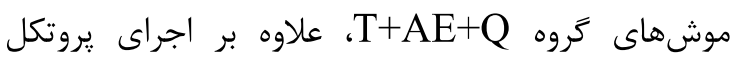

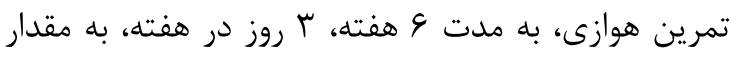

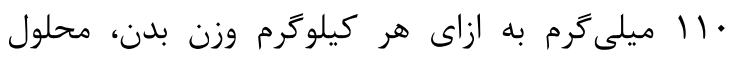
كوئرستين بهصورت تزريق زير صفاقى دريافت كردند.

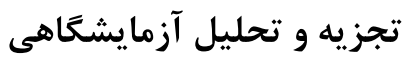

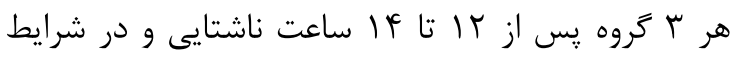

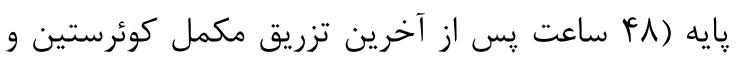

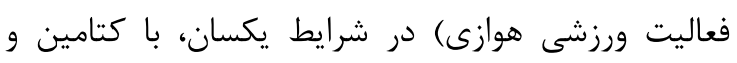

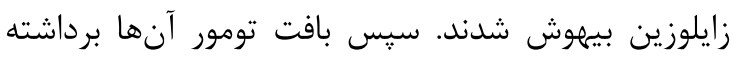

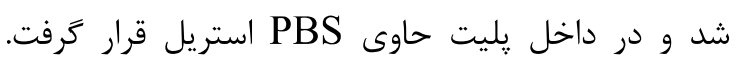
قسمت نكروز شده مركزى تومور و عروق خونى واخد و بافت

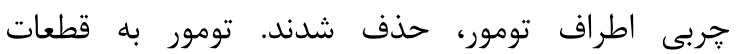

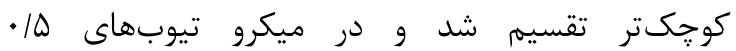
ميلىليترى قرار ترفت و بلافاصله در نيتروزن مايع فريز

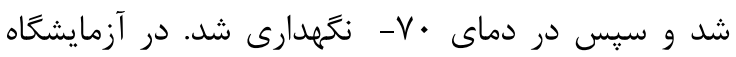

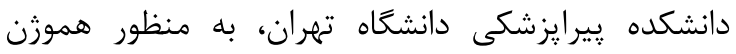

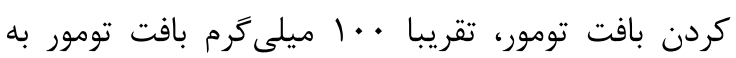

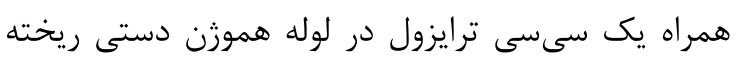
شد و بافت هموزن گرديد. مايع رويى لوله هموزن، براي

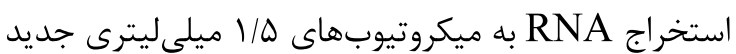

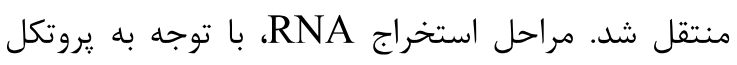
ترايزول ساخت شركت لايف تكنولوزى كشور آمريكا، انجام

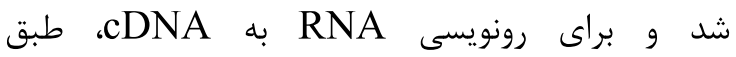

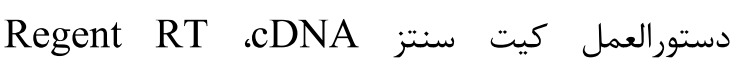

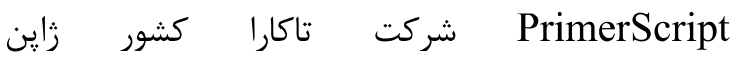
(Cat\#RR037A)، ميزان بيان عوامل مورد نظر سنجيده

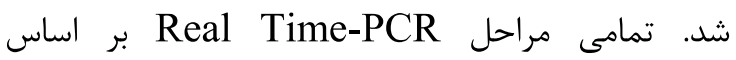

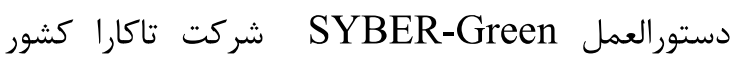
زاين (Cat\#RR820L)، انجام شد. از زن ACTB

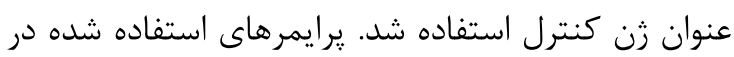
جدول ا ارايه شده است.
آنها بود، استفاده مىكردند. آب مورد نياز موشها نيز

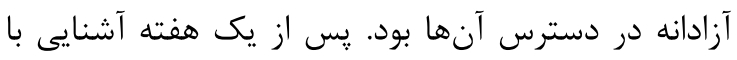

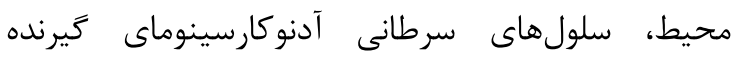

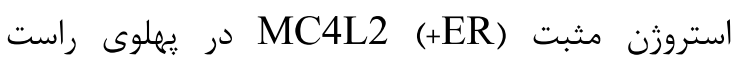
موشها و به روش زير جلدى تزريق شد. مصرف مكمل

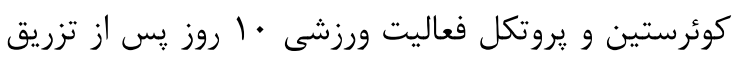
سلول هاى سرطانى آغاز شد. كشت سلول و نحوه ايجاد تومور مراحل كشت سلول و ايجاد تومور در آزمايشعاه كشت ستول سلول دانشكده بِيرايزشكى دانشكاه تهران، انجام شد. ابتدا

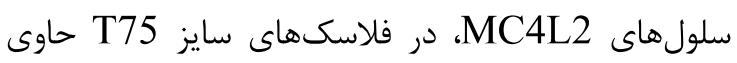

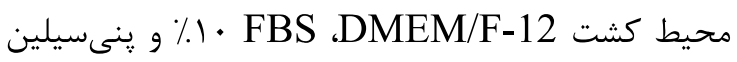
100ug/ml كشت داده شدند و يس از تكثير سلولها،

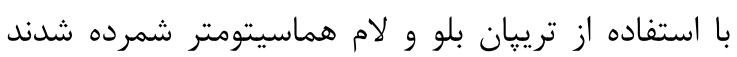

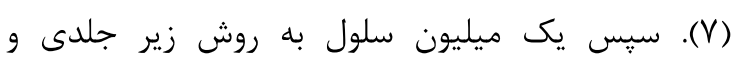

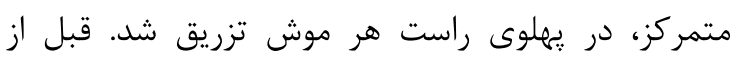

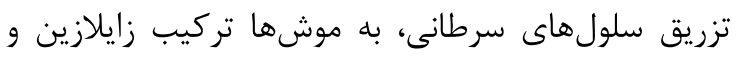
كتامين به صورت زير جلدى تزريق گرديد و و موشهانها

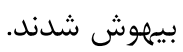
يروتكل تمرين هوازى شدي

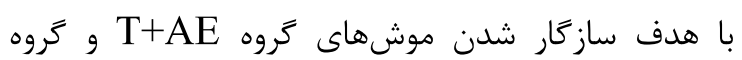

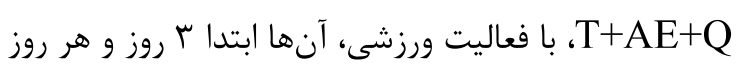

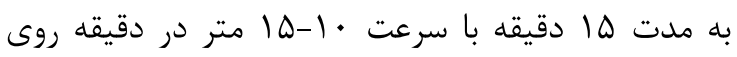

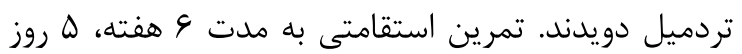
در هفته بر روى تردميل اجرا شد. در هفته اول جلسات

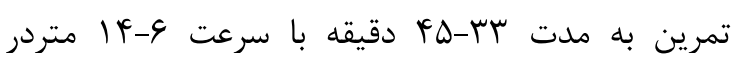
دقيقه، در هفته دوم جلسات تمرين

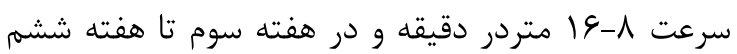

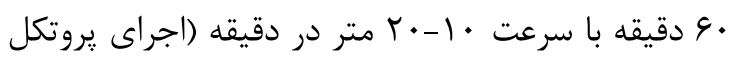

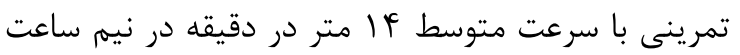

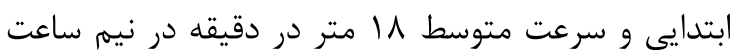
دوم دوره يروتكل تمرينى) انجام شد (با().

جدولا: توالى يرايمرهاى ثنها

\begin{tabular}{ccc}
\hline نام زَن & آغازَّر برَشتى \\
\hline TIE-2 & CACCAAGATCCACTGGAGGTTC (22N) & GCAGGTAGGAAGGATGCTTGTTG (23N) \\
VEGF-A & GTTTCGGGAACCAGACCTCTC (21N) & CCAAAGTGCTCCTCGAAGAGTC (22N) \\
ACT-b & CTGTCGAGTCGCGTCCAC (18N) & TCATCCATGGCGAACTGGTG (20N) \\
\hline
\end{tabular}




\section{يافتهها}

يافتهاى يزوهش نشان مىدهد يروتكل تمرين هوازى، تاثير معنادارى بر بيان TIE-2 و تروني

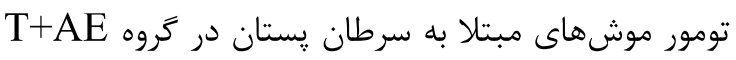

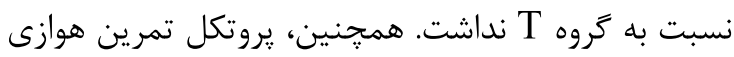

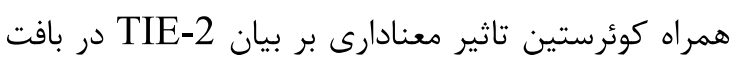

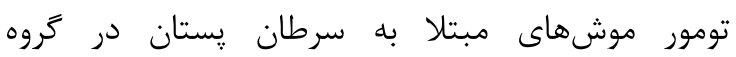
T+AE+Q در مقايسه با كروه T و كروه T+E نداشت، اما باعث كاهش معنادار بيان VEGF-A در مقايسه با

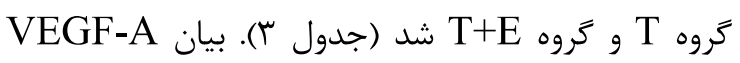

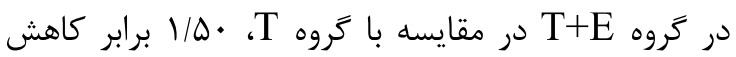

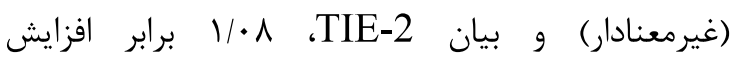

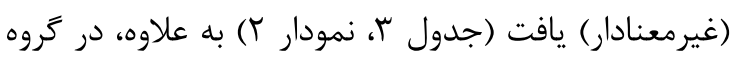

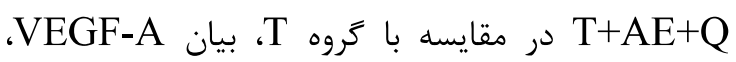

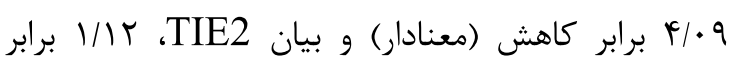

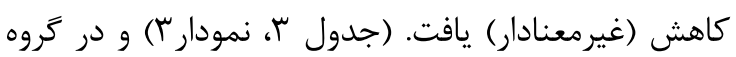

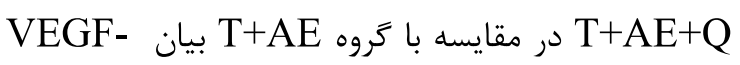

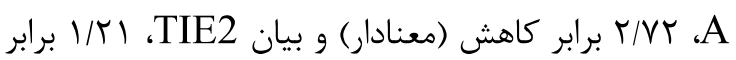

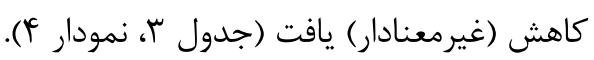

تجزيه و تحليل دادهها

بهمنظور كمىسازى مقادير بيان ثن، با تفريق

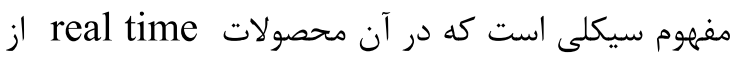

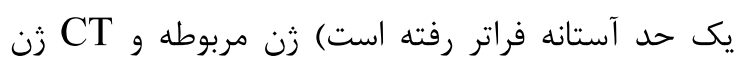
ACT-b محاسبه شد. سيس از تفريق $\Delta \mathrm{Ct}$

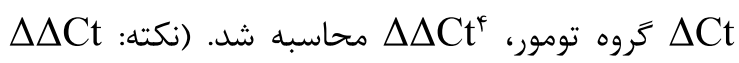

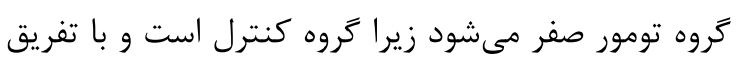

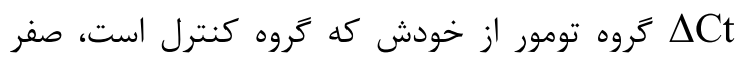

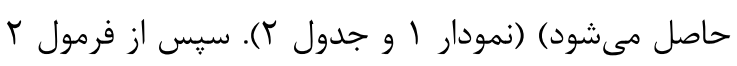
به توان Fold Change (به مفهوم تهند

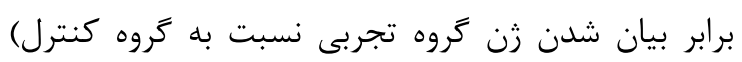

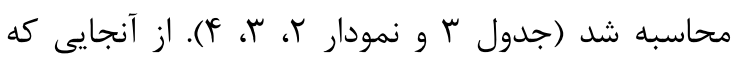

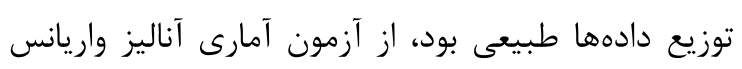

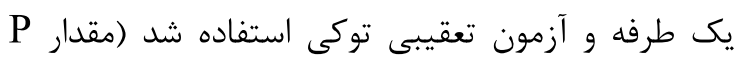

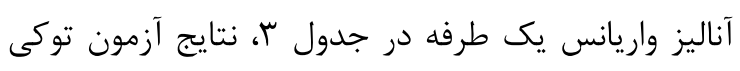

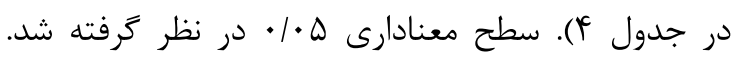

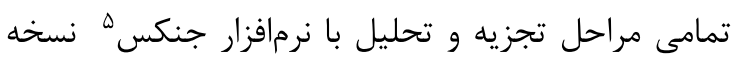

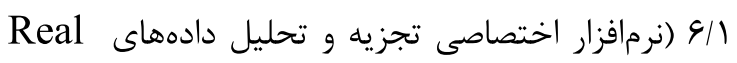
(Time-PCR

\begin{tabular}{|c|c|c|}
\hline TIE2 & VGEF-A & \\
\hline$\cdot / \cdot \pm \cdot / r q$ & $\cdot / \cdot \pm \cdot / r \Delta$ & تومور (T) \\
\hline$\cdot / 11 \pm \cdot / 4$ & $-\cdot / \Delta \Lambda \pm \cdot / \mu F$ & تومور +هوازى(T+E) \\
\hline$-\cdot / 10 \pm \cdot / T r$ & $-r / \cdot r \pm \cdot / r \Lambda$ & تومور +هوازى+كوئر ستين(T+AE+Q) \\
\hline
\end{tabular}

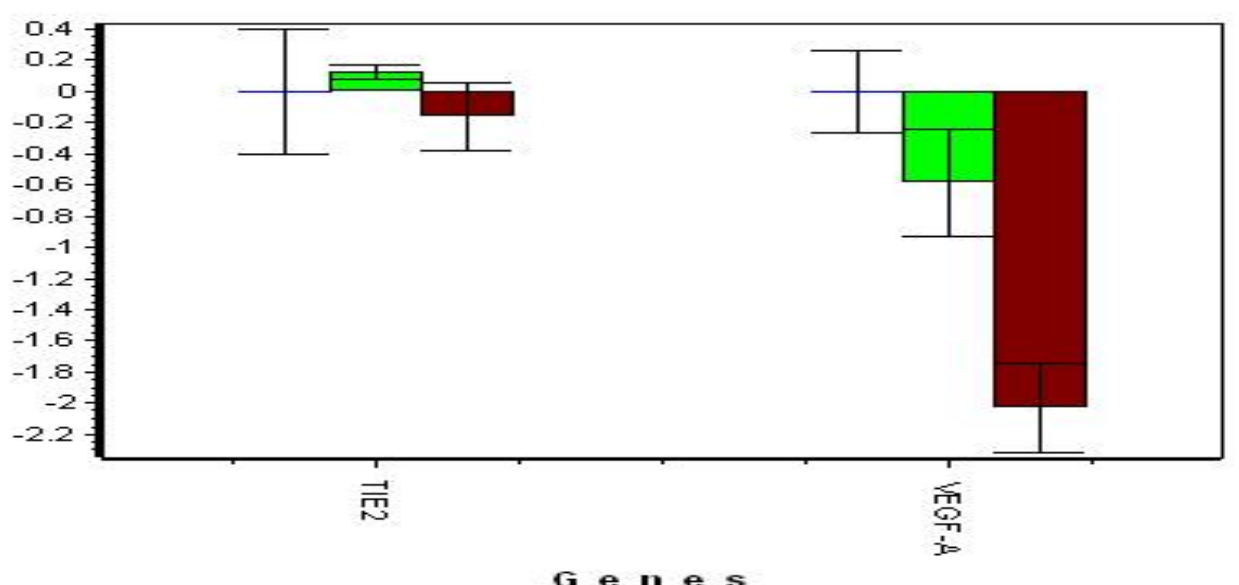




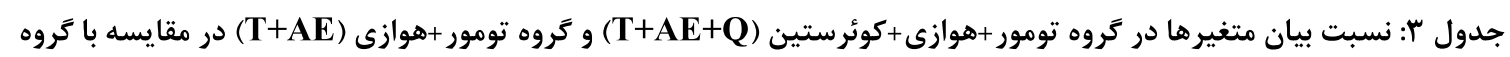
تومور (T)، نسبت بيان متغيرها در كروه تومور +هوازى+كوئرستين (T+AE+Q

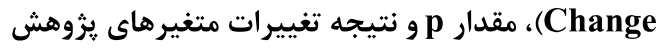

\begin{tabular}{|c|c|c|}
\hline TIE-2 & VEGF-A & نام زنها \\
\hline $1 / \cdot 1$ & $-1 / 0$ & Fold Change \\
\hline$-1 / 14$ & $-4 / \cdot q$ & Fold Change $5 ر و ه$ تومور +هوازى+كوئرستين نسبت به كروه تومور \\
\hline$-1 / 41$ & $-t / 2 t$ & Fold Change كروه تومور +هوازى+كوئرستين نسبت به كروه تومور +هوازى \\
\hline . IV & $* \cdot \cdot$ & $\mathbf{P}$ \\
\hline اختلاف غيرمعنادار & اختلاف معنادار & نتيجه \\
\hline
\end{tabular}

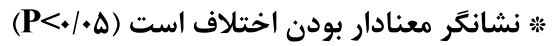

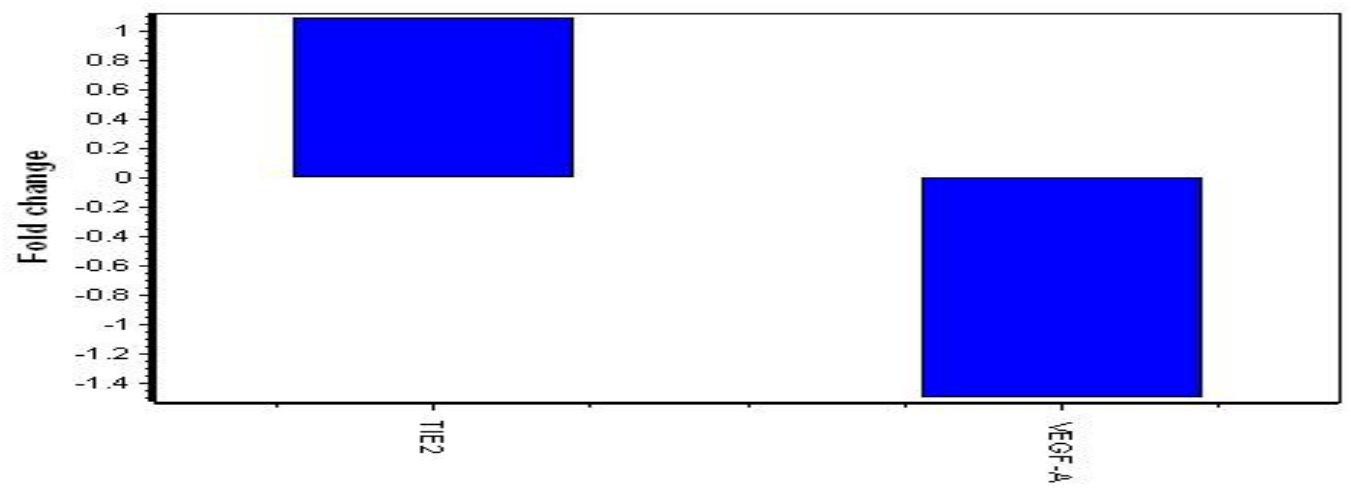

Genes

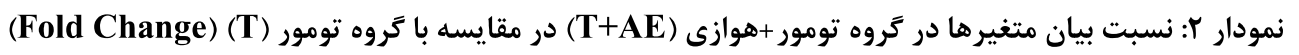

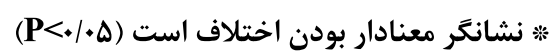

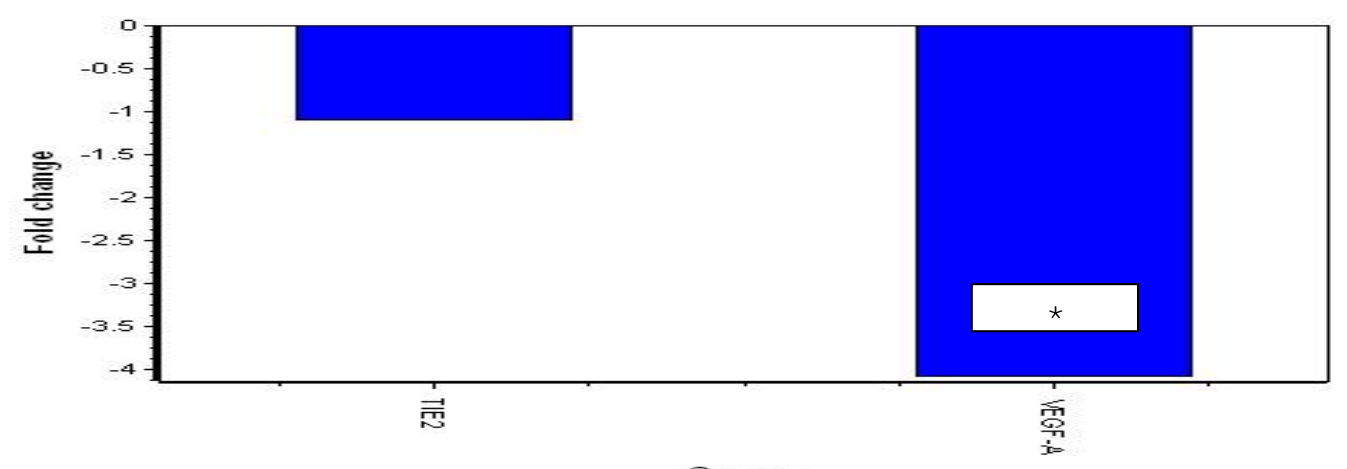

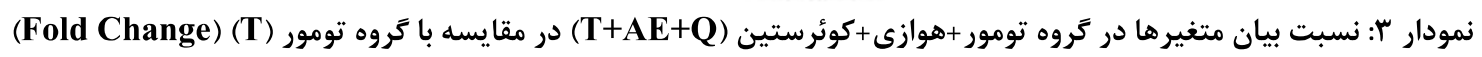

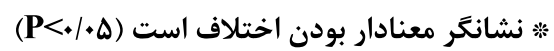

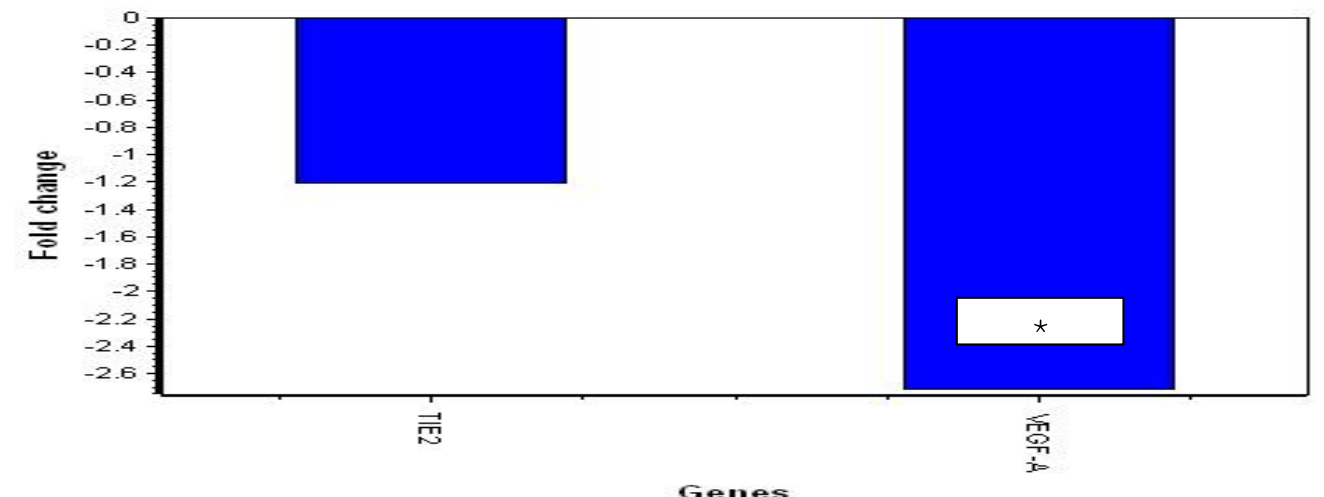

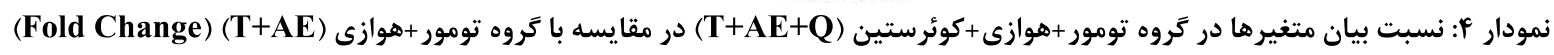

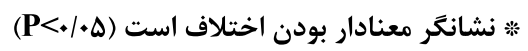




\begin{tabular}{|c|c|c|}
\hline 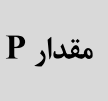 & $\begin{array}{c}\text { ميانگين اختلاف } \\
(\Delta \Delta \mathbf{C t})\end{array}$ & تروهاها \\
\hline \multirow{4}{*}{$\begin{array}{l}. / 94 \\
.19\end{array}$} & \multirow{4}{*}{$\begin{array}{l}. / 11 \\
. / 10\end{array}$} & آزمون توكى ويثه TIE-2 \\
\hline & & تومور (T) \\
\hline & & تومور +هوازى (T+AE) \\
\hline & & تومور +هوازى+كوئرستين (T+AE+Q) \\
\hline \multirow[b]{3}{*}{$\cdot / V^{F}$} & \multirow[b]{3}{*}{$\cdot / 4 V$} & آزمون توكى ويثه TIE-2 \\
\hline & & تومور +هوازى (T+AE) \\
\hline & & تومور +هوازى+كوئرستين (T+AE+Q) \\
\hline \multirow{4}{*}{$\cdot / \pi \Delta$} & \multirow[b]{3}{*}{$\cdot / \Delta \Lambda$} & آزمون توكى ويزه VEGF-A \\
\hline & & تومور (T) \\
\hline & & تومور +هوازى (T+AE) \\
\hline & $T / \cdot T$ & تومور +هوازى+كوئرستين (T+AE+Q) \\
\hline \multirow[b]{3}{*}{$* * 1 \cdot$} & \multirow{3}{*}{$1 / F F$} & آزمون توكى ويزه VEGF-A \\
\hline & & تومور +هوازى (T+AE) \\
\hline & & تومور +هوازى+كوئرستين (T+AE+Q) \\
\hline
\end{tabular}

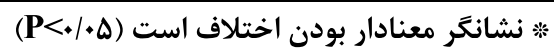

كه تاثير تمرين ورزشى هوازى را بر بيان TIE-2 در سردان

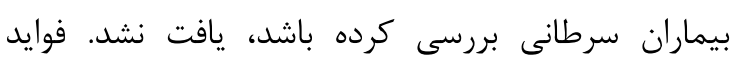

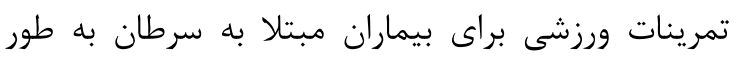

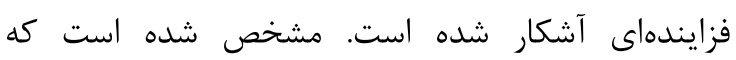

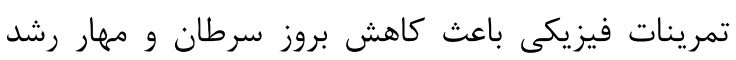

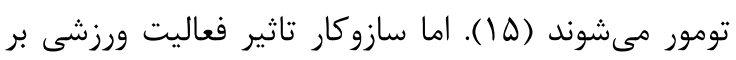

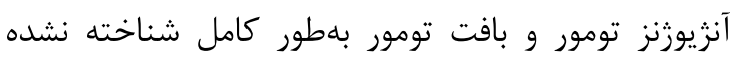
است. مشخص شده است كه تومور داراى محيطى ناهمكن

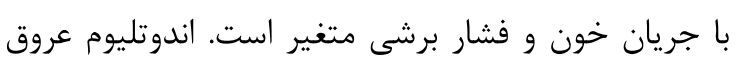

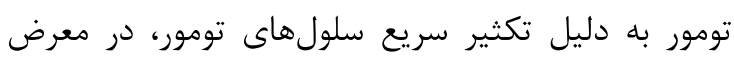
PH

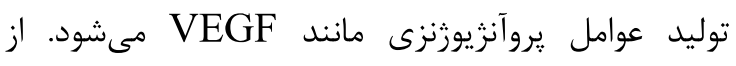

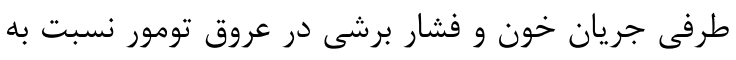

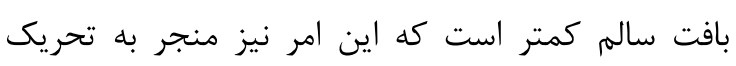

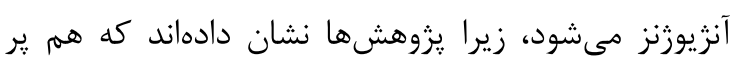

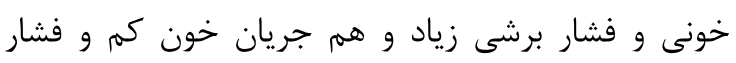

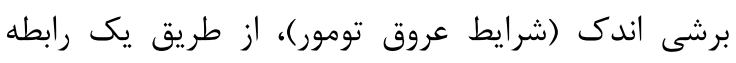

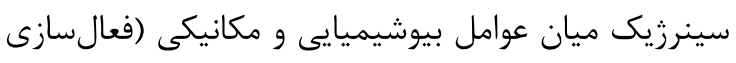
كانالهاى يونى، كانالهاى كاتيونى و كانال هاى

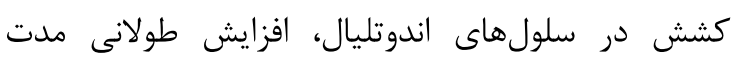
درون سلولى و افزايش قابل توجه توليد نيتريك الدوائل

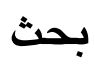

يزوهشها نشان دادند كه همراستا با افزايش متاستاز و رشد تومور در بيماران مبتلا به سرطان يستان، مقادير

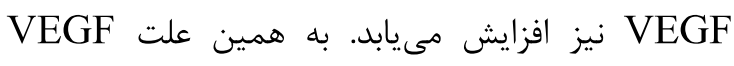

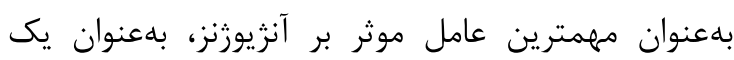

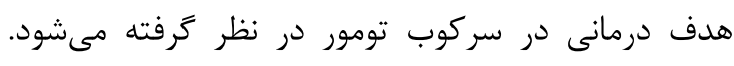

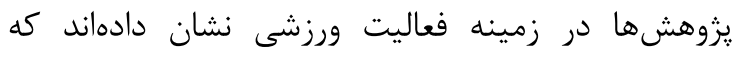

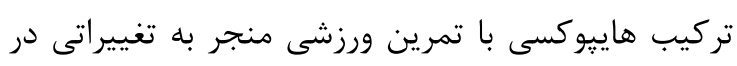

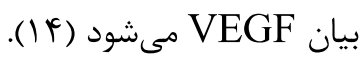

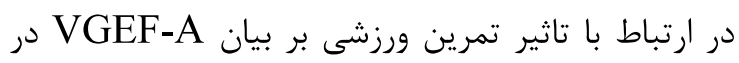

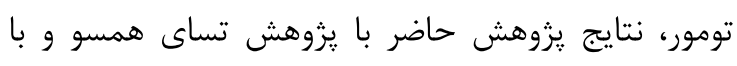

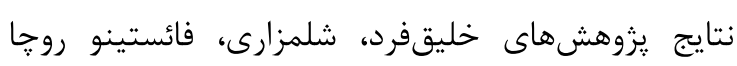

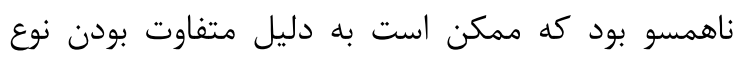

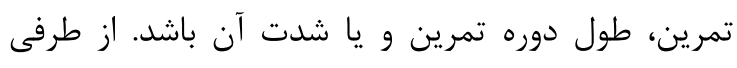

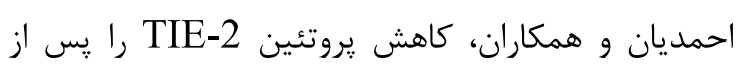

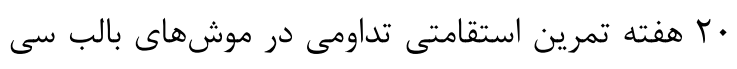

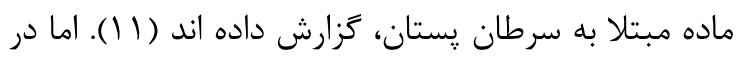

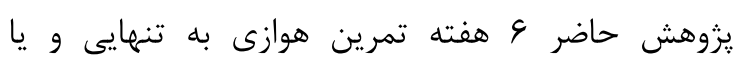

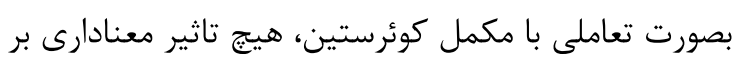

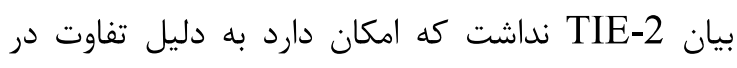

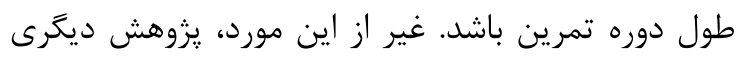


PI3K / Akt / mTOR ،MAPK/ ERK1/2 مسيرهاى ضدسرطانى، باعث كاهش رشد تومور مىشود.

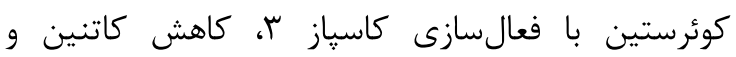
و و مهار فسفوريلاسيون HIF-1 ERK باعث از بين رفتن قابليت زنده ماندن سلولهاى فيون

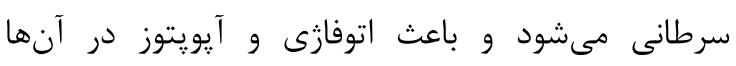

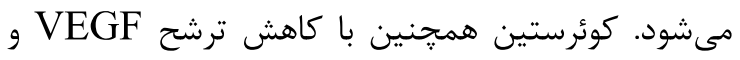

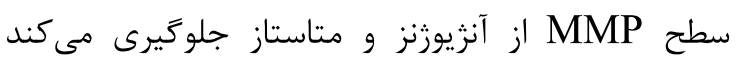

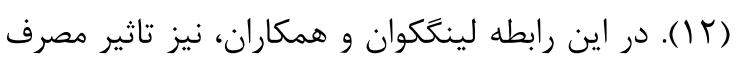

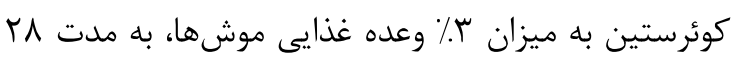

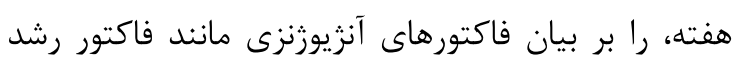

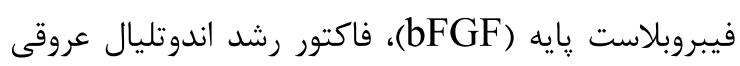
و و بروتئين H-ras برائ (VEGF) نمودند كه مصرف كوئرستين باعث كاهش بيان تمامى اين

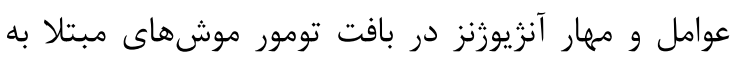
سرطان پستان مىشود (1) (1). داكسيان زائو و همكاران، نيز

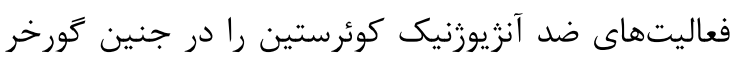

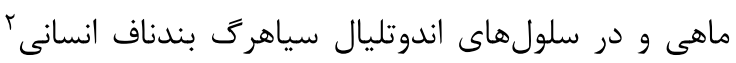

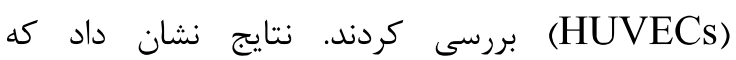
كوئرستين، حيات سلول را در HUVECs مختل

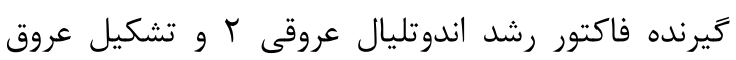
جديد را مهار كرد. آنها بيان كردند كه كوئرستين دارئ آنداى

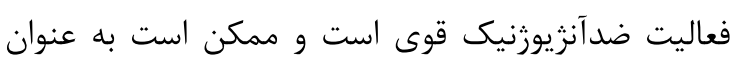

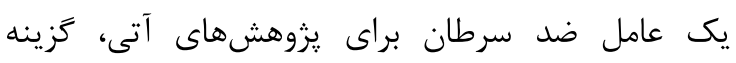

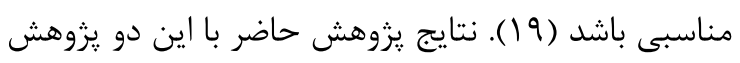

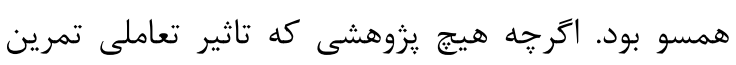

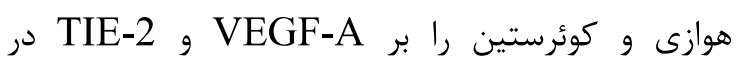
بيماران سرطانى، بررسى كرده باشد، يافت نشد.

\section{نتيجهكيرى}

با توجه به نتايج يزوهش، تعامل تمرين هوازى و مصرف كوفي

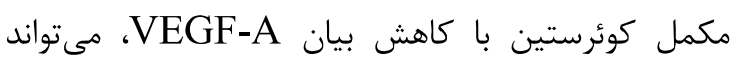
روند آنزيوزنز بافت تومور را مختل و رئن رشد تومور سرطان

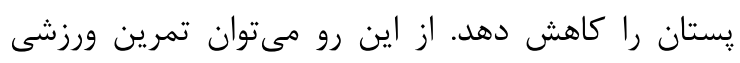

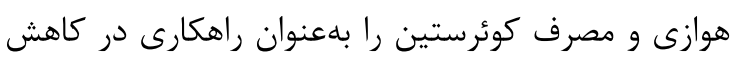

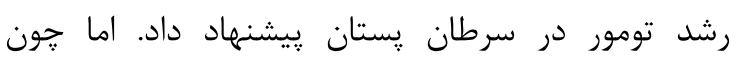

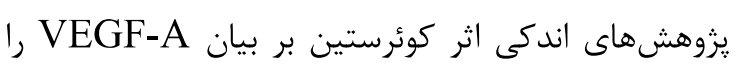
بررسى كردهاند و يزوهشى كه تاثير كونئرسين تعاملى بيان مصرف

\footnotetext{
${ }^{2}$ Human Umbilical Vein Endothelial Cells
}

اكسايد) باعث تحريك آنزيوزنز مىشود (ع) (1). بنابراين از

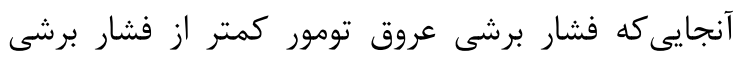

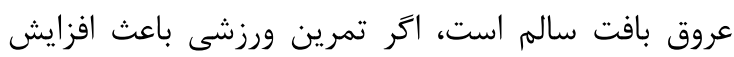

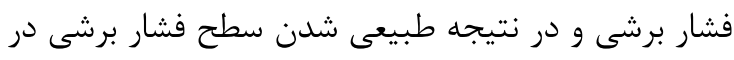

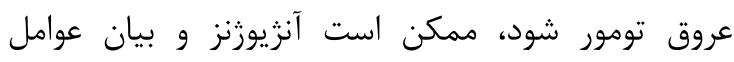
آنزيوزنزى همجيجون VEGF-A و يروهش حاضر 9 هفته تمرين هوازى با شدت متوسط،

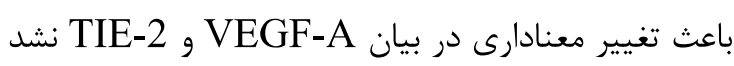

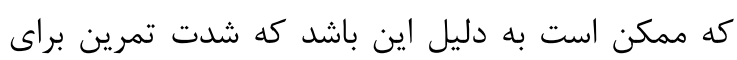

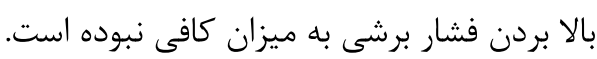

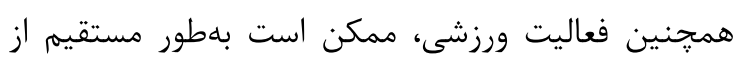

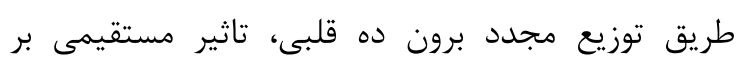

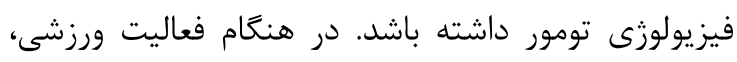

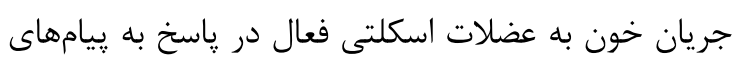
موضعى عروق، به منظور رفع نيازهاى متابوليسه، بهطور

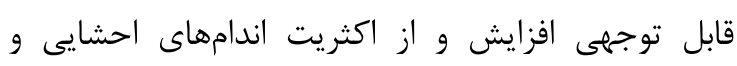

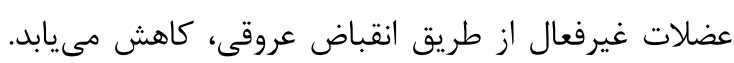

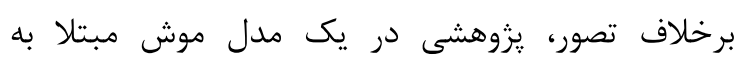

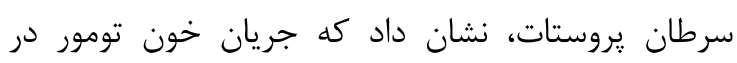

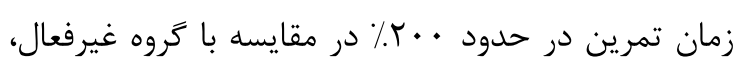

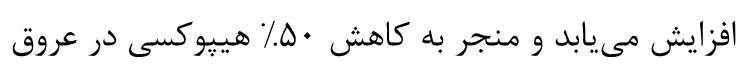

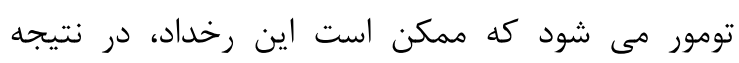

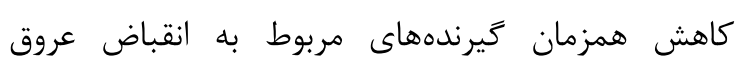

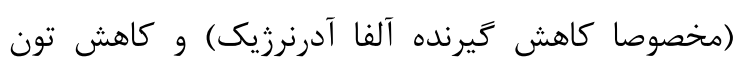

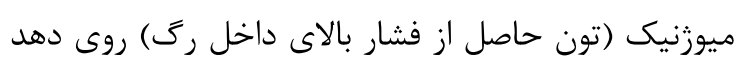
(IV) افزايش جريان خون تومور و در نتيجه كاهش هييوكسى و اسيدوز در عروق تومور شود، ممكن است باعث كاهش

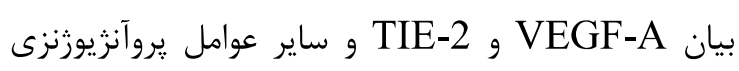
شود. بنابراين ممكن است دليل ديغر بى بتاثير بودن

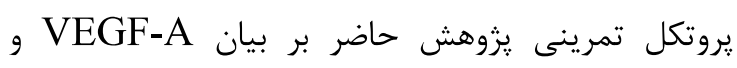

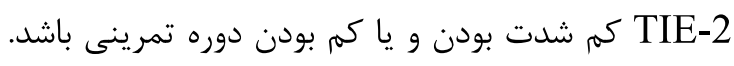

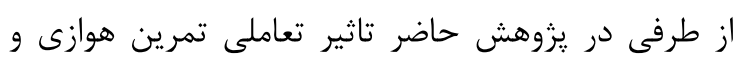

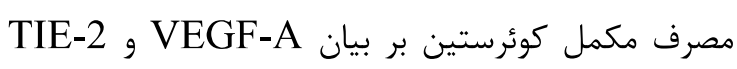

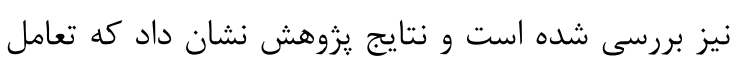

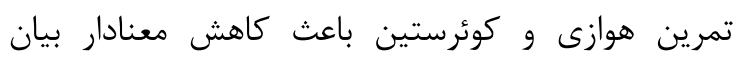

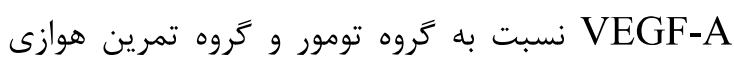
شد. اكرجه بر بيان TIE-2 تاثير معنادارى نداشت.

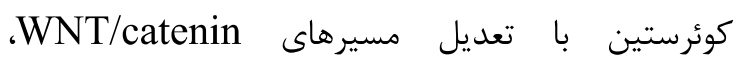




\section{تشكر و قدردانى}

اين يزوهش با حمايت مالى دانشگاه تربيت دبير شهيد

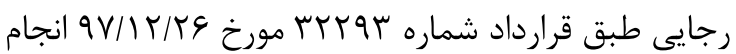
كرديده است و از تمامى افرادى كه در اين يزوهش

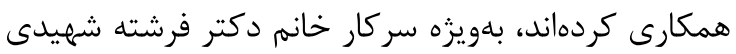
كه در تمامى مراحل يزوهش، در كنارم بودند، تقدير و تشكر مىنمايم.

$$
\begin{aligned}
& \text { تعارض منافع } \\
& \text { نويسندFان اعلام مىدارند كه هيج تعارض منافعى در } \\
& \text { يزوهش حاضر وجود ندارد. }
\end{aligned}
$$

$$
\begin{aligned}
& \text { كوئرستين و فعاليت ورزشى هوازى را بر بيان VEGF-A } \\
& \text { در سرطان يستان بررسى كرده باشد، نيز يافت نشد، لذا لذان }
\end{aligned}
$$

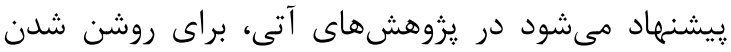

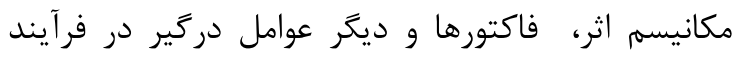

$$
\begin{aligned}
& \text { آنزيوزنز ارزيابى شوند و تاثير دوزهاى مختلف مكمل داني } \\
& \text { كوئرستين بر بيان VEGF-A بروسيى شونى شود. }
\end{aligned}
$$

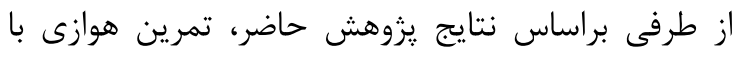

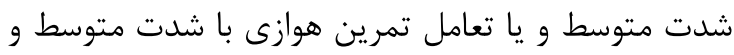

$$
\begin{aligned}
& \text { مكمل كوئرستين تاثير معنادارى بر بيان TIE2 نداشت و }
\end{aligned}
$$

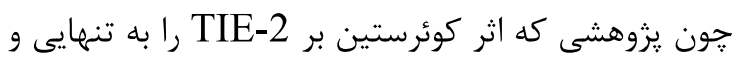

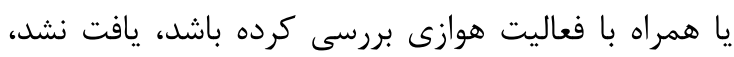

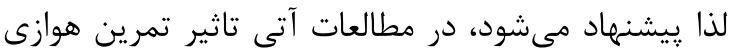

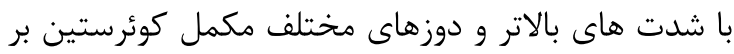

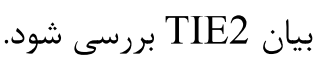

\section{References}

1. Jiang Y, Zou L, Lu WQ, et al. Foxo3a expression is a prognostic marker in breast cancer. PLoS One. 2013; 8(8):e70746.

2. Makrilia N, Lappa T, Xyla V, Nikolaidis I, et al. The role of angiogenesis in solid tumours: an overview. Eur J Intern Med. 2009; 20(7):663-71.

3. Kerbel RS. Tumor angiogenesis. The New England journal of medicine. 2008; 358(19): 2039-49.

4. Carmeliet P. Angiogenesis in life, disease and medicine. Nature. 2005; 438(7070):932-6.

5. Teicher, Beverly A, Ellis, Lee M, editors. Antiangiogenic Agents in Cancer Therapy. 2nd ed. Texas: Humana Press. 2008; 208-12.

6. Hojman P, Gehl J, Christensen JF, Pedersen BK. Molecular Mechanisms Linking Exercise to Cancer Prevention and Treatment. Cell Metab. 2018; 27(1):10-21.

7. Shalamzari SA, Agha-Alinejad H, Alizadeh S, Shahbazi S, Khatib ZK, Kazemi A, et al. The effect of exercise training on the level of tissue IL-6 and vascular endothelial growth factor in breast cancer bearing mice. Iranian journal of basic medical sciences. 2014; 17(4):231.
8. Tsai MS, Kuo ML, Chang CC, Wu YT. The effects of exercise training on levels of vascular endothelial growth factor in tumorbearing mice. Cancer Biomark. 2013; 13(5): 307-13.

9. Faustino-Rocha AI, Silva A, Gabriel J, Gil da Costa RM, Moutinho M, Oliveira PA, et al. Long-term exercise training as a modulator of mammary cancer vascularization. Biomed Pharmacother. 2016; 81(7):273-80.

10. Khalighfard S, Rajbi H, Gharakhanlou R, Setoudeh V. The Effect of 8 Weeks of Interval Aerobic Exercise before and after Induction of Breast Cancer on Serum Level of Irisin and Tumor Growth in Balb/c mice. Journal of Isfahan Medical School. 2018; 35(459):177584.

11. Ahmadian M, Azizbeigi K, Delfan M, Atashak S. Effects of 10 week continuous endurance training on angiopoietin-1 gene expression and the tie 2 protein in mice with breast cancer. Med J Tabriz Uni Med Sciences Health Services. 2019; 41(1):7-13.

12. Reyes-Farias M, Carrasco-Pozo C. The anticancer effect of quercetin: molecular implications in cancer metabolism. 
International journal of molecular sciences. 2019; 20(13):3177.

13. Schebeleski-Soares C, Occhi-Soares RC, Franzoi-de-Moraes SM, et al. Preinfection aerobic treadmill training improves resistance against Trypanosoma cruzi infection in mice. Appl Physiol Nutr Metab. 2009; 34(4):659-65.

14. Nasiri M, Peeri M, Matinhomaei $H$. Endurance Training Attenuates Angiogenesis Following Breast Cancer by Regulation of MiR-126 and MiR-296 in Breast Cancer Bearing Mice. International Journal of Cancer Management. 2014; 17(4):231-58.

15. Moore SC, Lee IM, Weiderpass E, Campbell PT, Sampson JN, Kitahara CM, et al. Association of Leisure-Time Physical Activity With Risk of 26 Types of Cancer in 1.44 Million Adults. JAMA Intern Med. 2016; 176(6):816-25.
16. Wragg JW, Durant S, McGettrick HM, Sample KM, Egginton S, Bicknell R. Shear stress regulated gene expression and angiogenesis in vascular endothelium. Microcirculation. 2014; 21(4):290-300.

17. Koelwyn GJ, Quail DF, Zhang X, White RM, Jones LW. Exercise-dependent regulation of the tumour microenvironment. Nat Rev Cancer. 2017; 17: 620-32.

18. Kong $\mathrm{L}, \mathrm{Wu} \mathrm{K}$, Lin $\mathrm{H}$. Inhibitory effects of quercetin on angiogenesis of experimental mammary carcinoma. Chinese Journal of Clinical Oncology. 2005; 2: 631-6.

19. Zhao D, Qin C, Fan X, Li Y, Gu B. Inhibitory effects of quercetin on angiogenesis in larval zebrafish and human umbilical vein endothelial cells. Eur J Pharmacol. 2014; 723: 360-7. 